\title{
The Unemployment Rate Amid the COVID-19 Pandemic: Propose the Best Practices Policy to Maintain Labor Market Stability
}

\author{
Nazaruddin Malik ${ }^{1}$, Muhammad Sri Wahyudi Suliswanto ${ }^{2 *}$, Mochamad Rofik ${ }^{3}$ \\ ${ }^{1}$ Department of Development Economics, Faculty of Economics and Business, Universitas Muhammadiyah Malang \\ ${ }^{2}$ Corresponding author, Department of Development Economics, Faculty of Economics and Business, \\ Universitas Muhammadiyah Malang (email: ms_wahyudi@umm.ac.id) \\ ${ }^{3}$ Center for Economics, Business and Entrepreneurship Development, Faculty of Economics and Business, \\ Universitas Muhammadiyah Malang
}

\begin{abstract}
This study analyzes the impact of the shocks caused by the COVID-19 pandemic on the labor market. The research is vital for expanding the literature about maintaining the unemployment rate amid crisis, ultimately reducing unnecessary social costs. The quantitative approach in this study uses a Granger causality test to understand the effect of the shock caused by the COVID-19 pandemic on unemployment. Meanwhile, the qualitative approach in this study uses literature related to economic growth, crisis management, and unemployment. Granger causality tests show that economic slowdown hurts the unemployment rate. Based on discussion and synthesis from works of literature, this paper recommends some of the policies to maintain growth and prevent a more severe collapse in the labor market; the government needs to sustain aggregate demand and supply. Also, ensure the supply chain runs well amid various restrictions. Besides, this paper also proposes that the government maximizes alternative budget resources. Meanwhile, strengthening the labor system and developing health and food security industries must be a priority policy amid-post the pandemic.
\end{abstract}

Keywords:

COVID-19; pandemic; unemployment; labor market

\section{Introduction}

The COVID-19 outbreak has had a significant impact on society around the world. With a rapid spread, COVID-19 not only created a health crisis and did additional damage through economic shocks. Starting with the collapse of issuers' prices on the stock market to the labor market. Recent data shows that during the second half of March 2020, job vacancies in the U.S. fell by $30 \%$ compared to the beginning of the year (Coibion et al., 2020). As a preliminary comparison, in the recession that began in 2007, the unemployment rate jumped high; in 2010 the peak of U.S unemployment reached 10.1\% (Schaal, 2012). However, when the U.S. experienced recession and the demand of the dollar weakened, emerging market countries actually "enjoyed" benefit. Emerging markets were flooded by foreign capital to strengthen the local currency, increase economic growth, and reduce the unemployment rate. The financial crisis in 2007 was obviously different compared to the crisis caused by the COVID-19 pandemic; since almost all countries in the world experience pressure both on the supply and demand sides. This condition is exacerbated by a high degree of uncertainty because no one has been able to ascertain when the COVID-19 pandemic will end. Looking at the effects of the spread of the COVID-19 outbreak and the socio-economic impacts caused, it seems more appropriate to compare it to the shocks caused by natural disasters or war with its massive impact. 
The work of governments worldwide is also getting more challenging; besides dealing with the economic crisis, the government must also solve its main problem, which is the virus spread. Some countries take extreme policies by closing territories (lockdown); others moderate by emphasizing social distancing and work from home (WFH). The implementation of lockdown and social distancing means that industrial centers must stop operating or reduce working hours, and "non-primary" businesses experience temporary closure. As a result, this policy will damage the supply chain and reduce the aggregate supply. The supply chain's disruption and the aggregate supply's collapse have disrupted the company and business balance sheets. It is necessary to restructure both the production sector and laborers. Some companies make soft decisions such as dismissing temporary employees, cutting salary to extreme measures such as layoffs (Ashwin \& Lytkina, 2004; Jagannathan et al., 2013; Padrón \& Burger, 2015).

The fundamental question is, how much unemployment will be created as a result of the economic slowdown? To the best of our in-depth study, no literature clearly shows the impact of slowing economic growth caused by the virus outbreak on the unemployment rate. But some articles about SARS and MERS could be used as references. Specific studies on the impact of the pandemic in Hong Kong show that SARS hurts the economy, especially the hotel sector. However, this study indicates that mass layoffs and redundancies are not widespread. The moving labor policy and cutting costs seems to be a more major option in the strategy of maintaining business continuity (G. O. M. Lee \& Warner, 2005). Meanwhile, research shows that MERS outbreak increases the likelihood of labor and temporary employment and sharply reduces working hours for middleaged and old age groups compared to the young group. In particular, working hours are decreasing even in work with a low risk of epidemic exposure. Besides, unintentional unemployment and underemployment show a higher probability. Compared to the groups in their 30s and 40s, younger people are highly likely to be unemployed, especially accidental unemployment after the spread of MERS (A. Lee \& Cho, 2016).

Although there is no specific literature discussing the impact of a pandemic as big as the COVID-19 on the labor sector, we can take important insight from some research papers focusing on the relationship between economic growth and the unemployment rate during recession. Recent research involving data over the past 50 years shows that U.S. decreasing GDP through slow economic growth leads to an increasing unemployment rate (Mandel \& Liebens, 2019). Other studies through idiosyncratic volatility shocks in search-and-matching models also support that an increase in the idiosyncratic uncertainty firms faces leads to higher unemployment and more dispersion in firm growth rates under the recession (Schaal, 2012). Different from the U.S., Japan is a country with high resiliency in dealing with crises. The statistic shows that unemployment in Japan has not had a major reaction to the decline in aggregate demand during the crisis, both compared to other countries and with historical experience its self (Hijzen et al., 2015). The strong resilience condition, especially in the labor market, was also demonstrated by the United Kingdom (U.K.) during the 2008 recession. The U.K. economic system proved to withstand a larger impact (Gregg \& Wadsworth, 2010).

Amid the COVID-19 pandemic, social and economic movements are limited cause less productivity, which represents an economic slowdown that will impact the labor market. Research by Hijzen et al. (2015), Mandel \& Liebens (2019), and Schaal (2012) shows that economic growth has a significant reverse effect on the level of unemployment with varying elasticity and coefficient of determination. 
Preliminary studies on the impact of COVID-19 on the labor market in the U.S. show that 20 million people lost their jobs in early April. Furthermore, participation in the labor force experienced a decline of $7 \%$ and was the largest during the 2008-2016 timeframe (Coibion et al., 2020). Data from recessions caused by other health crises such as SARS and MERS also show not much difference; empirical studies expose economic shocks caused by SARS and MERS being able to disrupt the labor market (A. Lee \& Cho, 2016; G. O. M. Lee \& Warner, 2005).

Labor market disruption will increase social problems such as financial hardship and severe poverty, debt, homelessness and housing stress, atrophy of job skills, and worse health system (Akwara et al., 2013; O'Campo et al., 2015; Schmitz, 2011). On a broader scale, unemployment will also increase the degree of social conflict and political instability. In a long-term scenario, it is not only the unemployed who have a high intention of social conflict but also vulnerable workers. If these risks are not resolved immediately, it will undoubtedly impact the high costs that must be borne financially, socially, and politically (Cramer, 2010; Saint-Paul, 2005). Therefore, considering the effects of unemployment and its derivative in dealing with the crisis, it is crucial to measure the necessary strategic steps in order not to make a worse impact. Moreover, the crisis caused by the COVID-19 pandemic has different characteristics than the crisis in general.

Research by Gregg \& Wadsworth (2010); Hijzen et al. (2015); Mandel \& Liebens (2019); and Schaal (2012) show that although the U.S., U.K., and Japan are developed countries, the impact of economic shocks during the crisis has a heterogeneous impact on the labor market and unemployment. Therefore, response policies caused by the same crisis are also very likely to differ even though they have the same principles. This study performs a novel analysis using the same method, data, and timeframe to understand economic growth and unemployment. Not only data from the U.S., U.K., and Japan, we also take additional data from Indonesia to represent emerging markets. Understanding the labor market characteristics in the four countries and their experience in dealing with economic recessions is valuable knowledge in formulating policies to avoid a larger shock in the labor market amid-post the COVID-19 pandemic.

Furthermore, preliminary studies on the impact of the COVID-19 pandemic on the labor market and unemployment conducted by Coibion et al. (2020) have not provided recommendations regarding policies that must take to reduce impacts and speed recovery. By understanding the characteristics of an economic slowdown and the unemployment rate; and conducting literature studies on crisis management due to financial and health crises, this research contributes to propose policies in reducing the impact of the crisis caused by the COVID-19 pandemic especially shocks to the labor sector. In addition, this study also expands the paper on the impact of the health crisis on the economy and the labor market as carried out by A. Lee \& Cho (2016) and G. O. M. Lee \& Warner (2005)

This paper begins with a brief background on the impact of the COVID-19 pandemic and the impact of the economic slowdown on increasing unemployment. Then the relationship between economic growth and the unemployment rate is presented at the beginning of the results section. Then, this paper reviews selected research articles as a first step to constructing the best policy formulation in reducing the impact of the pandemic.

\section{Methods}

Basically, it is hard to accurately predict the labor market shock caused by the crisis in the health sector. However, in general, the crisis is marked by a shock in economic growth 
followed by an increase in layoffs, and the indication has been seen since the beginning of the spread of COVID-19. Furthermore, understanding the characteristics of the relationship between economic growth and the unemployment rate will provide a projection of the severity and solutions that need to be taken to maintain the labor market amid (post) pandemic. United States of America (U.S.), United Kingdom (U.K.), and Japan (JPN) were chosen as the main samples. In addition to their long experience in dealing with crises in previous periods, the three developed countries also represent economic strength in their respective regions, America, Europe, and Asia. However, considering the economic structure, employment system, and best practice policies in the face of uncertainty, the selection of the three countries is not proportional, especially to represent emerging markets. Therefore this study involves Indonesia (INA) as a representation of the emerging market as one of the four selected samples.

Granger causality test is one of the common methods used to predict time series data, especially in the economic field. This test can provide a strong predictive argument regarding the effect of variable $\mathrm{X}$ on $\mathrm{Y}$ and vice versa. By understanding a two-way causality relationship, policymakers can stress one side or both sides of a policy. In this study, the results of the Granger causality test between the rate of economic growth and unemployment can be one of the main considerations for policymakers to emphasize policy in growth stability, improving worker skills or both of them. The Granger causality test of this study follows equations 1-4 with the significance based on the F test (Wiebe, Ray, Maswabi, Kgathi, \& Branas, 2016; Zhang, Chen, Lu, \& Guo, 2011). The data of unemployment rate collected from the International Labor Organization (ILO) and economic growth data is taken from the official statistical agency of each sample. The time span of the unemployment rate and economic growth data in this study is 1999:Q1-2019:Q4.

$$
\begin{aligned}
& \mathrm{Y}=\alpha_{0}+\alpha_{1} \mathrm{X}+\alpha_{2} \mathrm{X}_{(-1)}+\alpha_{3} \mathrm{X}_{(-2)}+\beta_{1} \mathrm{Y}_{(-1)}+ \\
& \beta_{2} \mathrm{Y}_{(-2)}+\mathrm{U}_{1} \\
& \mathrm{Y}=\alpha_{0}+\beta_{1} \mathrm{Y}_{(-1)}+\beta_{2} \mathrm{Y}_{(-2)}+\mathrm{U}_{2} \\
& \quad \text { Null hypothesis }\left(\mathrm{H}_{0}\right): \alpha_{1}=\alpha_{2}=0
\end{aligned}
$$

$\mathrm{Y}$ causes $\mathrm{X}$ if $\mathrm{H}_{0:} \alpha_{1}=\alpha_{2}=0$ can be rejected.

$\mathrm{X}=\alpha_{0}+\alpha_{1} \mathrm{Y}+\alpha_{2} \mathrm{Y}_{(-1)}+\alpha_{3} \mathrm{Y}_{(-2)}+\beta_{1} \mathrm{X}_{(-1)}+$

$\beta_{2} \mathrm{X}_{(-2)}+\mathrm{U}_{1}$

$\mathrm{X}=\alpha_{0}+\beta_{1} \mathrm{X}_{(-1)}+\beta_{2} \mathrm{X}_{(-2)}+\mathrm{U}_{2}$

Null hypothesis $\left(\mathrm{H}_{0}\right): \alpha_{1}=\alpha_{2}=0$

$\mathrm{X}$ causes $\mathrm{Y}$ if $\mathrm{H}_{0}: \alpha_{1}=\alpha_{2}=0$ can be rejected.

After understanding the characteristics of shocks in the labor sector, this study also offers several policies to reduce the impact and accelerate the recovery of the labor sector after the pandemic. This policy offer is prepared based on a Systematic Literature Review (SLR) study through stages: a) Planning, related to the development of review questions and plan methods or protocols; b) Data Collection Stage, search for strings, screening titles, and abstracts, filtering \& assessment, and data extraction; c) Analysis Stage, descriptive and thematic analysis); d) Discussion and Synthesis Stage (see more detail at Fig.1).

The Planning phase begins by setting a research question (RQ). RQ is used as a main reference in the literature search process. This study aims to answer how public policy is related to unemployment during a crisis (pandemic), especially in four countries, the U.S., U.K., Japan, and Indonesia. The initial database used was Google Scholar selected based on accessibility with the keywords pandemics, recession, labor markets, unemployment, policy. In addition, data were also obtained from books, news, and websites to support the analysis process. The next stage is the analysis and synthesis of findings and ends with discussing the SLR results. The Conclusion section will contain a summary of the findings obtained, according to the RQ that has been set. 
Figure 1.

The flow of Systematic Literature Review (SLR)

$R Q$ : What are the policies to reduce the impact and accelerate the recovery of the labor sector amid (post) crisis (pandemic)?
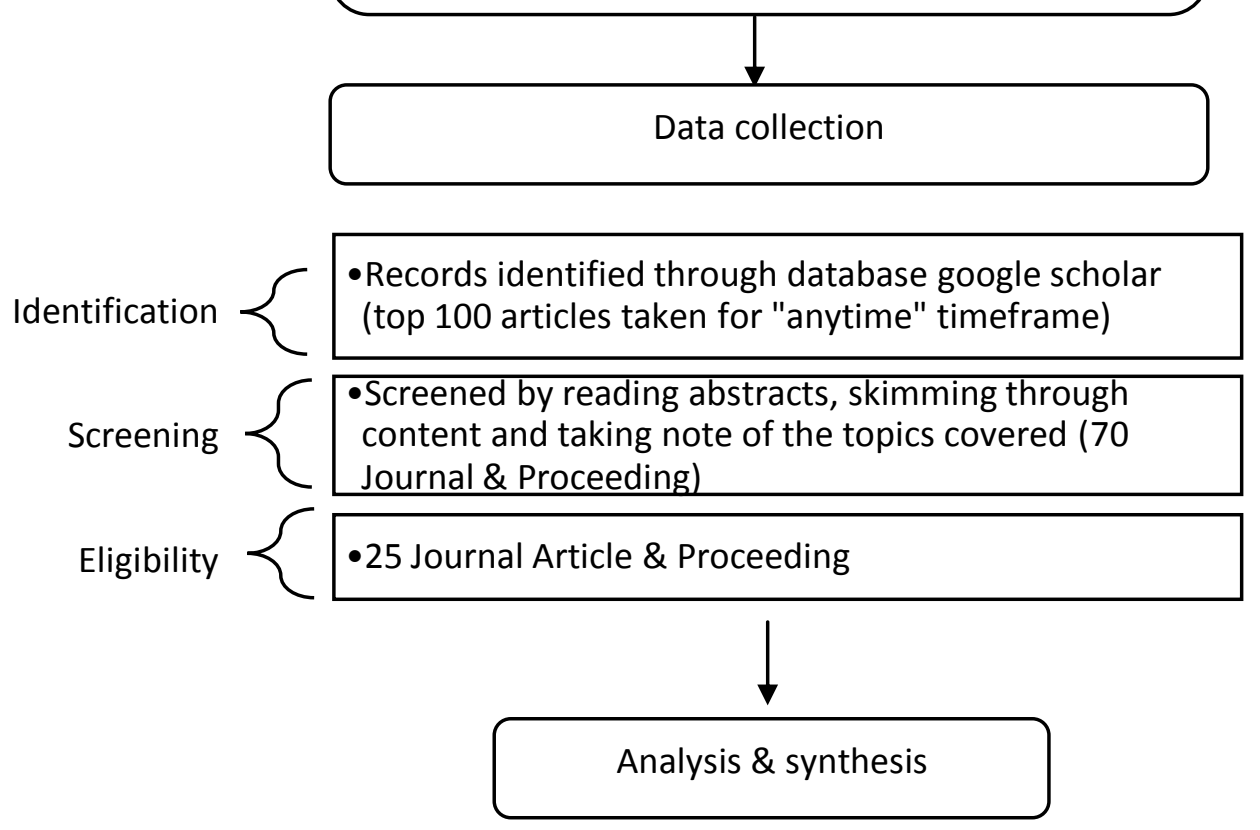

Sources: Adapted from Okoli (2015); Weißer et al. (2020); and Xiao \& Watson (2019)

\section{Eligible sources}

Cynamon, Fazzari, \& Setterfield (2012); (Fort, Haltiwanger, Jarmin, \& Miranda (2013); Quon, Zeghal, \& Maingot (2012); (DuyganBump et al., 2015); (Hijzen et al. 2015); Duygan-Bump et al. (2015); Cynamon et al., (2012); Longstaff, 2010); (Manoppo, 2015); (Ramadhita, 2012); Gregg Paul \& Wadsworth Jonathan (2010); (Barlevy, 2011); Elsby, Hobijn, \& Sahin (2010); Figura \& Barnichon (2014); (Furlanetto \& Groshenny, 2014); Sedláček (2014); (Schaal, 2012); (Chuma, 2002); (Azizah et al., 2015; Charles et al., 2013). Cramer (2010); and Saint-Paul (2005); (Akwara et al., 2013); O'Campo et al. (2015); Schmitz, (2011).

\section{Result and Discussion Granger Causality Test}

Granger causality test is used to show the pattern of relationships between economic growth and unemployment. Table 1 shows the relationship between economic growth and unemployment in the four countries selected as the sample. Based on the causality test results in the second lag, Indonesia, Japan, and the United Kingdom have a one-way relationship, the relationship of economic growth to unemployment. However, it should be noted that the one-way relationship between Indonesia is not as strong as the relationship that occurred in Japan and the United Kingdom. This finding indicates that the unemployment rate in Japan and the 
Table 1.

Result of Granger causality test

\begin{tabular}{|c|c|c|c|c|c|}
\hline Null Hypothesis & Obs & F-Statistic & Prob. & Result & $\begin{array}{l}\text { direction of the } \\
\text { relationship }\end{array}$ \\
\hline UN_INA does not Granger Cause GDP_INA & 26 & 0.06302 & 0.9391 & Ho accepted & one-way relationship \\
\hline GDP_INA does not Granger Cause UN_INA & & $1.55298^{* *}$ & 0.2350 & Ho declined & (GDP -> Unemployment) \\
\hline UN_JPN does not Granger Cause GDP_JPN & 26 & 0.05857 & 0.9433 & Ho accepted & one-way relationship \\
\hline GDP_JPN does not Granger Cause UN_JPN & & $3.21308^{*}$ & 0.0606 & Ho declined & (GDP $\rightarrow$ Unemployment) \\
\hline UN_UK does not Granger Cause GDP_UK & 26 & 1.46820 & 0.2530 & Ho accepted & one-way relationship \\
\hline GDP_UK does not Granger Cause UN_UK & & $3.20280^{*}$ & 0.0611 & Ho declined & (GDP -> Unemployment) \\
\hline UN_US does not Granger Cause GDP_US & 26 & $1.66350^{* *}$ & 0.2135 & Ho declined & two-way relationship \\
\hline GDP_US does not Granger Cause UN_US & & $1.57550^{* *}$ & 0.2304 & Ho declined & $\begin{array}{c}\text { (GDP <-> } \\
\text { Unemployment, })\end{array}$ \\
\hline
\end{tabular}

Notes: ${ }^{*}$ ) significance level of $\alpha 10 \% ;{ }^{* * *}$ ) significance level of $\alpha 25 \%$

Sources: Results of data analysis with Eviews 11

United Kingdom is susceptible to economic growth; this is possibly because most of the population works in the formal sector, both manufacturing and service industries, which are the main booster of the GDP. This condition drives the labor markets in Japan and United Kingdom to be sensitive to the pace of economic growth. Meanwhile, in Indonesia, economic growth did not have as strong an impact as in the U.K. and Japan, possibly because most Indonesian workers work in the informal sector (Asian Development Bank, 2016). Furthermore, an extreme difference occurs in the United States, which shows a two-way relationship between economic growth and unemployment with a significant degree at $\alpha 25 \%$. The twoway relationship in this country means that reducing unemployment will cause economic growth. At the same time, any increase in economic activity will cause unemployment decreases.

Amid the COVID-19 pandemic, the pattern of the relationship between economic growth and unemployment in the sample countries can provide an initial prediction of how much the labor market will fall. In addition, the results of the Granger causality test, which are in the same direction, GDP affects unemployment in the U.K., Japan, and Indonesia, indicating that the policymaker should prioritize policies in maintaining growth, such as tax incentive on the supply-side and subsidies in the demand side. Meanwhile, in the U.S., the result is a twoway relationship, which means besides stressed growth it also emphasizes the labor sector itself, such as employment insurance training, short courses, etc.

\section{COVID-19 Pandemic and Labor Market}

Based on the Granger Causality Test in Table 1, it can be concluded that the relationship between economic growth in each country has different characteristics. However, it can be ascertained that it would inevitably affect the unemployment rate when the crisis hit and economic growth fell. Cynamon, Fazzari, \& Setterfield (2012) revealed that the economic slowdown was marked by a decline in company income, so that the company had difficulty meeting obligations. The crisis conditions due to COVID-19 showed symptoms in that direction; large-scale social restriction made the industry reduce productivity and affected the lower supply side; several policies ranging from the cessation of industrial operations to the closure of "non-primary" business posts will affect the demand side. The combination of the decline in demand and supply means the company will begin to face liquidity problems. On the other hand, when companies are still able to maintain their obligations, generally, recessions have an impact on increasing capital 
costs, so companies need more funds to keep running (Fort et al., 2013; Quon et al., 2012).

Amid a downturn, financing from banks or bond issuance can be hampered because the market is cautious and tends to choose risk-free assets. Therefore, companies select the path of financial tightening ranging from mild levels such as temporary dismissal of employees to massive levels such as lay off. Data during the 2008 recession phase showed that banks in the United States tended to be more selective in providing funding (Duygan-Bump et al., 2015). The banking policy can be understood because the data shows that companies with significant external funds tend not to survive amid a crisis. Amid the high dependence on external funds and reduced demand simultaneously, companies will find it challenging to earn capital and ultimately survive by lowering production and workers. During the Great Recession, the unemployment rate in the U.S. rose sharply from $4.5 \%$ in mid-2007 to a peak of more than $9 \%$ in the fall of $2009 .{ }^{1}$

Furthermore, the Japan Ministry of Labor Report in 1979 provides clear evidence for tackling the crisis. The report advises that large-scale companies in the manufacturing industry laid off workers or offered voluntary layoffs with a figure reaching 20 percent. Meanwhile, for medium-scale companies, the reduction of workers reached $30 \%$, while for small and micro companies, respectively 26 percent and 17 percent. The total number of workers dismissed in the manufacturing industry during the same period amounted to around 700,000 and in all sectors reached 1.6 million. To reduce the impact of the 1979 oil recession and oil crisis, the Japanese government finally issued an employment insurance program through the Employment Adjustment Subsidy (EAS). This program is government assistance to companies that are

See details at https://tradingeconomics.com/unitedstates/unemployment-rate experiencing financial problems. This program is government assistance to companies that are experiencing financial problems. This program was seen as successful because it reduced the potential unemployment, initially estimated at 5.4 percent to 2.0 percent (Chuma, 2002).

During a health crisis due to COVID-19, we clearly understand that the first thing that happened was a shock to the aggregate demand. Therefore, the government's step in providing social assistance to maintain purchasing power is the right policy. Unfortunately, COVID-19 disrupts not only aggregate demand but also aggregate supply. Learning from Japan's best practices, as Hijzen et al. (2015) stated and the tendency of difficulty in financing by Duygan-Bump et al. (2015), the government also needs to provide a stimulus policy for the industry. When the government only focuses on maintaining purchasing power and does not think about the supply side, it will bring excessive inflation; of course, this will cause another disruption (Cynamon et al., 2012).

\section{Labor Market in Post-Pandemic}

The 2008 recession in the U.S. provides valuable lessons; the labor market is slow enough to recover. In 2013 unemployment rates in the U.S. are still higher than in 2007. Three years after the peak recession in 2008, the U.S. unemployment rate was still above $8 \%$. It is suspected that this is due to a sectoral and geographical mismatch between available jobs and labor. ${ }^{2}$ This conjecture is supported by several studies which show that the effectiveness of matching job vacancies with unemployment has decreased dramatically (Elsby et al., 2010; Figura \& Barnichon, 2014). Studies show that the estimated reduction in matching efficiency increases the actual unemployment rate by around $1.3 \%$ and the natural rate by $2 \%$ during the Recession (Furlanetto \& Groshenny, 2014).

\footnotetext{
${ }^{2}$ See more at http://www.minneapolisfed.org/
} news_events/pres/speech_display.cfm?id=4525\& 
Sedláček (2014) estimates that a major recession miss-match affects $1 / 4$ of the total unemployment that occurs. Another study also shows that the labor market had difficulty reconciling after the 2008 recession (Schaal, 2012). In the 1998 crisis in Japan, statistics also showed that people got more new jobs through private work placement agencies after the recession than state-owned agencies (Chuma, 2002). Therefore, coordination between government, companies, vocational training institutions, and universities must be maintained and improved to minimize errors in post-crisis policymaking. By identifying the causes of low labor absorption, the government will have a more comprehensive understanding of diversifying the labor market post-pandemic.

Although in 2008 the U.K. also experienced a severe recession, its impact was minimal on job loss. Gregg \& Wadsworth (2010) revealed at least three things that reduced the U.K. labor market shock. First, entrepreneurs enter a recession in good financial condition; second, a rapid rate cut, bank rescue, and fiscal stimulus from the government have helped maintain company cash flow and avoid a more severe labor crisis. Third, workers receive nominal wage moderation very early in this recession. Although wages tend to decrease, workers will not experience layoffs.

Linking the 2008 crisis in the U.K. with the COVID-19 outbreak, for the first point, of course, is difficult to do. The high prevalence of COVID-19 infections globally shows that very few countries are ready to deal with this condition. Also, we feel this applies at the company level, which undoubtedly have had no preparation in facing this pandemic. So, what can be done during and after this pandemic are the second and third points. We do not recommend that the central bank reduce interest rates during a pandemic because it will not be impacted. Still, we strongly support reducing interest rates when the outbreak has begun to subside and the economy starts to reverse. Furthermore, we also encourage companies to make salary adjustments during the pandemic and slowly return to normal conditions when the pandemic gradually improves.

For example, if a company becomes less valuable or less productive because of shocks during a recession, not much can be done through monetary policy. The role of the government might be more appropriate in simplifying regulations and ensuring the running of the supply chain, however, if the work is less valuable due to decreased aggregate demand due to market friction, the government is freer in market intervention through monetary and fiscal policies. So it can be concluded that not only the number of job seekers and vacancies are impacted but also to understand why companies are hesitant to employ labor (Barlevy, 2011).

Labor-intensive development programs can also be a solution in the transition period. Community empowerment activities are beneficial for changing unemployed behavior, both their knowledge and attitude. Productive efforts carried out by several groups also open up employment opportunities for the unemployed. Besides, community empowerment also emphasizes community participation to find their problems, as well as with work programs that are appropriate to regulate the implementation for its sustainability to reduce unemployment. The intended target of community empowerment is an unemployed group that needs support from the government. Labor-intensive development, as the determinant of public policies to improve the quality of the resources, in turn, encourages increased business income to be able to contribute towards the recipient of regional income (Azizah et al., 2015; Charles et al., 2013). For example, the results achieved from all community empowerment programs and activities have been able to reduce unemployment in Sampang Regency, East Java, 
Indonesia, by $3 \%$ of the total unemployment (Azizah et al., 2015). This report indicates that during the new normal transition period, the government could also utilize labor-intensive development programs to maintain and reduce unemployment.

\section{Best Practice Policy}

The main discussion of this paper, in general, can be divided into two main parts, namely unemployment management policies and managing budget constraints. The policy for handling unemployment can be classified into three phases (see Fig. 2). First, there are policy recommendations during the pandemic; second is the policy we call the transition phase, and third is the policy post-pandemic. Furthermore, findings from previous studies show that the majority of policies are designed to provide intervention both on the demand and supply side. However, we understand that each country's budget capability is quite different. Alternative funding resources are needed to control the pandemic and economic impact, especially on the labor market.

\section{Managing unemployment amid a crisis}

In the first phase, due to severe contractions and large-scale social restrictions, declining productivity, and purchasing power, the government needs to provide subsidies to maintain aggregate demand. On the supply side, the government also needs to offer various incentives to large-scale industries and SMEs to reduce the possibility of mass layoffs as much as possible. Besides, due to many restrictions during the pandemic, the policy will disrupt the supply chain. Therefore, the government also needs to intervene through its instruments to ensure supply chain sustainability. In this first phase, the government also needs to prepare protocols for the transition phase when the transmission rate of COVID-19 begins to decline and the economy starts to reverse. This preparation is essential so that the outbreak remains under control and the initial economic recovery (transition phase) is not disrupted. We also recommend that the government builds a labor database by involving the industrial sector to avoid mismatches between the labor market and industry.

Figure 2.

\section{Unemployment management policies}

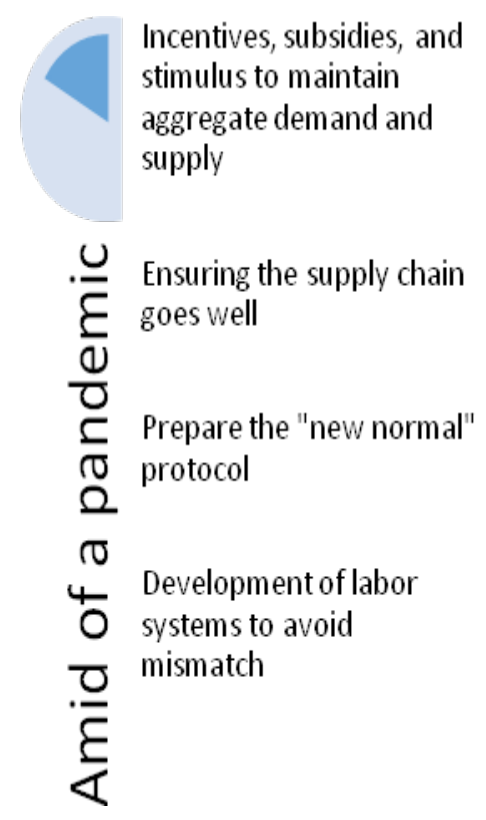

Incentives, subsidies, and stimulus to maintain aggregate demand and supply

Ensuring the supply chain goes well

Prepare the "new normal" protoco

Development of labor systems to avoid mismatch

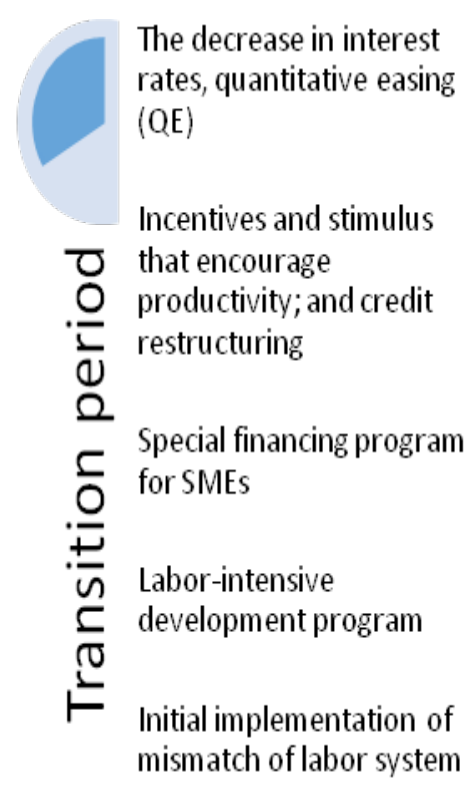

Develop strategic industries, especially in the field of food and health securities

$\cup$ Develop supply chain resilience

Strengthening the labor system

Full Implementation of the mismatch of labor system 
In the second phase, we assume the outbreak has been hampered; health protocols have begun to be applied in every line, including industry, business, and trade. In this phase, we recommend for the central bank to start reducing interest rates and initiate quantitative easing (QE) while the government provides a stimulus for both large-scale industries and SMEs and credit restructuring. The incentive in this phase is not a defense stimulus but a stimulus to encourage productivity and acceleration. Besides, the government can also handle unemployment through laborintensive programs, both short-term and longterm oriented. The labor-intensive program is an alternative when the labor market is still waiting for the industrial world to recover as fully as before the pandemic. It would be better if the labor-intensive programs offered can also be oriented to long-term business so that it can have a multiplier effect. This program is suitable for driving the economy, especially in rural and sub-urban areas, with a focus on workers with low-medium skills.

In the third phase, the COVID-19 pandemic makes us aware that a country cannot always depend on other countries. Furthermore, the government needs to pay more attention to increasing the competitiveness of national producers and industries to further reduce their dependence on foreign producers and industries, especially for strategic sectors such as food and medicine. Learning from the pandemic, the government and companies also need to prepare an emergency protocol for any extraordinary condition. Strengthening the national labor system also needs to be renewed, for example, by implementing a labor-saving policy during a pandemic through a particular social security program. These strategic policies are essential to reduce the impact caused by future health crises.

Several points of recommendation are expected to reduce the unemployment rate caused by the COVID-19 pandemic, maintain vulnerable jobs due to the crisis, and in general so that the labor system does decline further. These points aim to make the labor market quickly improve after experiencing severe shocks during the pandemic. Furthermore, Cramer (2010) and Saint-Paul (2005), stated that preventing the labor market from falling too deeply will reduce the probability of social and political conflict. Tackling unemployment will also prevent widespread poverty, better health coverage, and lower homelessness (Akwara et al., 2013; O'Campo et al., 2015; Schmitz, 2011).

\section{Managing budget constraints}

Amid a crisis, the first funding alternative to cover the budget deficit is the issuance bond. This policy requires a high level of caution because, during a recession, investors will be more selective in considering the fundamental aspects and prospects of a country's economy. The countries with weak fundamentals generally need to offer more giant coupons to the market. Therefore, we suggest that when the government adopts a policy of issuing a "pandemic bond," it is best to issue them in the medium and long term - this policy is designed to anticipate the ongoing crisis because the pandemic comes with many uncertainties (Longstaff, 2010).

The second alternative is to use bilateral diplomacy. In times of crisis, a country can utilize diplomacy to get bilateral and multilateral financing. Bilateral and multilateral loans through diplomacy can be an alternative to acquiring loans with low interest rates. Many factors influence the success of this second alternative, such as longstanding trade relations, cooperation in defense, and various other cooperation. However, we argue that the art of diplomacy and high-level political lobbies are needed to strengthen bargaining value. Although this alternative is challenging to use in meeting all needs, if this alternative can be implemented, it will reduce the burden on the state treasury (Manoppo, 2015). 
The third alternative is central bank intervention through a burden-sharing mechanism. This mechanism allows the central bank to buy government bonds directly to narrow the budget deficit. Furthermore, to maintain liquidity, the central bank can provide lower interest rates, and quantitative easing as the Central Bank of Japan did (Matousek et al., 2019). The impact of quantitative easing on Japanese banks' credit standards and systemic risk leads to softened credit standards for approving loan applications, and bank systemic risk decreases following the expansion of asset purchase programs (Vu, 2020). Still, the crisis caused by the COVID-19 pandemic, as explained in section two, results in decreased demand and the supply side. Therefore, when not careful in providing monetary policy and economic stimulus, a country can get caught up in hyperinflation. This hyperinflation occurs because of increased demand amid low productivity. Therefore, we suggest that central banks apply open market operations when the pandemic starts to subside and the economy is preparing to reverse.

The fourth alternative is through social funds. This paper takes the example of Indonesia. With most Muslim populations, the potential funds are obtained from zakat, infaq, and sadaqah (ZIS). In research conducted by the Center for the Study of Religion and Culture (CSRC), it found that the potential for zakat in Indonesia reaches 19.3 trillion IDR. This amount consists of 5.1 trillion IDR in goods and 14.2 trillion IDR in cash. At the same time, Public Interest Research and Advocacy Center (PIRAC) states that the potential for zakat in Indonesia annually ranges from 10 to 15 trillion IDR. BAZNAS also mentioned the national zakat potential of 217 trillion IDR, 82.7 trillion IDR potential zakat for households, 2.4 trillion IDR of zakat BUMN, and potential zakat savings of 17 trillion IDR (Ramadhita, 2012). Although the realization is not yet maximal, ZIS funds can be used as a partial instrument to maintain aggregate demand.

\section{Conclusion}

The results of the Granger causality test show that economic growth has a different level of significance for each country. However, the analysis indicated that the contraction that occurred in economic growth hurt the unemployment rate. Based on our discussion, this study highlights some important points to reduce the impact of the crisis caused by the COVID-19 pandemic, especially for maintaining growth and the labor force and reducing the possibility of socio-political impact. Without going through a long debate, we will reach a mutual consensus that the first step is to ensure that the pandemic can be controlled by implementing various health protocols. Therefore, this paper recommends several things beyond pandemic control. Our recommendations for maintaining the labor force are divided into three main parts: 1) maintaining the aggregate demand and aggregate supply; 2) optimize the alternative budgeting, and 3) avoid mismatch in the labor market. However, we also emphasize that the priority of these recommendations may differ depending on the characteristics of each country.

The first thing to do is to maintain aggregate demand and supply. To deal with the spread of the pandemic, the government needs to keep purchasing power by providing subsidies through various instruments such as direct cash assistance and income tax relief. Meanwhile, the government can provide credit restructuring and funding reforms with low interest to maintain the supply side. The derivative policy that needs to be taken ensures the supply chain is not too choked up amid the global interconnection. Therefore, instruments owned by the government can intervene to ensure the supply chain is running well. At least there are two benefits when maintaining the supply chain; avoiding supply delays and reducing production costs due to scarcity or obstruction. Maintaining supplyside and purchasing power would reduce the 
impact of shock due to COVID-19 so that the sustainability of production and labor is under control.

Second, concerning aspects of budgeting. Amid the crisis, as explained in the first point, many companies will experience financial problems. Therefore, the government provides subsidies and a stimulus for both large-scale industries and SMEs. On the other hand, at the same time, the government also provides subsidies to maintain purchasing power. This policy will undoubtedly burden the budget of the country. Alternative funding, starting issuing "pandemic bonds," burden sharing, bilateral loans, and social funds, needs to be optimized. This paper also recommends that the central bank provide quantitative easing and lower interest rates to accelerate economic growth during the recovery.

Third, avoid labor mismatches. In the discussion section of this paper, it can be seen that the mismatch after the recession has also become a severe matter of increasing unemployment. This finding can be one of the bases for the government to improve the labor system by involving industry and education institutions. For the national labor system, the social securities program amid a pandemic needs to be given attention. Also, to become resilient after the pandemic, each country needs to strengthen its strategic industries, especially in the health and food security sectors.

\section{References}

Akwara, A. F., Akwara, Ngozi F, Enwuchola, John, Adekunle, Udaw, \& Joseph E. (2013). Unemployment and Poverty: Implications for National Security and Good Governance in Nigeria. International Journal of Public Administration and Management Research.

Ashwin, S., \& Lytkina, T. (2004). Men in Crisis in Russia: The Role of Domestic Marginalization. In Gender and Society. https://doi.org/10.1177/0891243203261263
Asian Development Bank. (2016). Analysis of Trends and Challenges in the Indonesian Labor Market. Asian Development Bank $(A D B)$ Paper on Indonesia. https://doi. org/10.1016/J.RCP.2015.08.004

Azizah, R. N., Zauhar, S., \& Soeaidy, M. S. (2015). Pemberdayaan Masyarakat Dalam Mengurangi Angka Pengangguran di Kabupaten Sampang. Wacana, Jurnal Sosial Dan Humaniora, 18(03), 203-2012. https:// doi.org/10.21776/ub.wacana.2017.018.03.7 Barlevy, G. (2011). Evaluating the Role of Labor Market Mismatch in Rising Unemployment. Economic Perspectives, 3, 82-96.

Charles, K. K., Hurst, E., \& Notowidigdo, M. J. (2013). Equilibrium nemployment and Capital Intensity under Product and Labor Market Imperfections. October, 7180.

Chuma, A. H. (2002). Employment adjustments in Japanese firms during the current crisis. Industrial Relations, 41(4), 653-682. https:// doi.org/10.1111/1468-232X.00268

Coibion, O., Gorodnichenko, Y., \& Weber, M. (2020). Labor Markets During the COVID-19 Crisis: A Preliminary View. SSRN Electronic Journal. https://doi. org/10.2139/ssrn.3574736

Cramer, C. (2010). Unemployment and Participation in Violence. World Development Report 2011.

Cynamon, B. Z., Fazzari, S. M., \& Setterfield, M. (2012). Understanding the great recession. After the Great Recession: The Struggle for Economic Recovery and Growth, 9781107015(1), 3-30. https://doi. org/10.1017/CBO9781139059589.004

Duygan-Bump, B., Levkov, A., \& MontoriolGarriga, J. (2015). Financing constraints and unemployment: Evidence from the Great Recession. Journal of Monetary Economics, 75, 89-105. https://doi. org/10.1016/j.jmoneco.2014.12.011

Elsby, M. W. L., Hobijn, B., \& Sahin, A. (2010). The labor market in the great recession. 
Brookings Papers on Economic Activity. https://doi.org/10.1353/eca.2010.0001

Figura, A., \& Barnichon, R. (2014). The Effects of Unemployment Benefits on Unemployment and Labor Force Participation: Evidence from 35 Years of Benefits Extensions. Finance and Economics Discussion Series. https://doi. org/10.17016/feds.2014.065

Fort, T. C., Haltiwanger, J., Jarmin, R. S., \& Miranda, J. (2013). How firms respond to business cycles: The role of firm age and firm size. IMF Economic Review. https:// doi.org/10.1057/imfer.2013.15

Furlanetto, F., \& Groshenny, N. (2014). Mismatch shocks and unemployment during the great recession. Journal of Applied Econometrics, 21(August 2012), 1-21. https://doi.org/10.1002/jae

Gregg Paul, \& Wadsworth Jonathan. (2010). Employment in the 2008-2009 recession. Economic and Labour Market Review, 4(8). https://link.springer.com/content/ pdf/10.1057\%2Felmr.2010.111.pdf.

Hijzen, A., Kambayashi, R., Teruyama, H., \& Genda, Y. (2015). The Japanese labour market during the global financial crisis and the role of non-standard work: A micro perspective. Journal of the Japanese and International Economies, 38(9391), 260-281. https://doi.org/10.1016/j.jjie.2015.09.003

Jagannathan, R., Kapoor, M., \& Schaumburg, E. (2013). Causes of the great recession of 2007-2009: The financial crisis was the symptom not the disease! Journal of Financial Intermediation. https://doi. org/10.1016/j.jfi.2012.06.002

Lee, A., \& Cho, J. (2016). The impact of epidemics on labor market: identifying victims of the Middle East Respiratory Syndrome in the Korean labor market. International Journal for Equity in Health, 15(1), 1-15. https://doi. org/10.1186/s12939-016-0483-9

Lee, G. O. M., \& Warner, M. (2005). Epidemics, labour markets and unemployment: The impact of SARS on human resource management in the Hong Kong service sector. International Journal of Human Resource Management, 16(5), 752-771. https://doi. org/10.1080/09585190500083202

Longstaff, F. A. (2010). The subprime credit crisis and contagion in financial markets. Journal of Financial Economics. https://doi. org/10.1016/j.jfineco.2010.01.002

Mandel, C., \& Liebens, P. (2019). The Relationship between GDP and Unemployment Rate in the U.S. International Journal of Business and Social Science, 10(4), 17-24. https://doi. org/10.30845/ijbss.v10n4p3

Manoppo, V. (2015). Utang luar Negeri Indonesia (Perspketif Politik). 3(2), 54-67. http:// repositorio.unan.edu.ni/2986/1/5624.pdf

Matousek, R., Papadamou, S., Šević, A., \& Tzeremes, N. G. (2019). The effectiveness of quantitative easing: Evidence from Japan. Journal of International Money and Finance. https://doi.org/10.1016/j. jimonfin.2019.102068

O'Campo, P., Molnar, A., Ng, E., Renahy, E., Mitchell, C., Shankardass, K., St. John, A., Bambra, C., \& Muntaner, C. (2015). Social welfare matters: A realist review of when, how, and why unemployment insurance impacts poverty and health. Social Science and Medicine. https://doi.org/10.1016/j. socscimed.2015.03.025

Okoli, C. (2015). A guide to conducting a standalone systematic literature review. Communications of the Association for Information Systems. https://doi. org/10.17705/1cais.03743

Padrón, B. R., \& Burger, K. (2015). Diversification and Labor Market Effects of the Mexican Coffee Crisis. World Development. https:// doi.org/10.1016/j.worlddev.2014.11.005

Quon, T. K., Zeghal, D., \& Maingot, M. (2012). Enterprise Risk Management and Firm Performance. Procedia - Social and Behavioral Sciences. https://doi. org/10.1016/j.sbspro.2012.09.042 
Ramadhita, R. (2012). Optimalisasi Peran Lembaga Amil Zakat Dalam Kehidupan Sosial. Jurisdictie, 24-34. https://doi. org/10.18860/j.v0i0.2182

Saint-Paul, G. (2005). The Political Consequences of Unemployment. SSRN Electronic Journal, May, 1-46. https://doi.org/10.2139/ ssrn. 145753

Schaal, E. (2012). Uncertainty, Productivity and Unemployment in the Great Recession. Federal Reserve Bank of Minneapolis, Mimeo, 1-59. http://www. frbatlanta.org/documents/news/ conferences/12employment_schaal.pdf

Schmitz, H. (2011). Why are the unemployed in worse health? The causal effect of unemployment on health. Labour Economics. https://doi.org/10.1016/j. labeco.2010.08.005
Sedláček, P. (2014). Match efficiency and firms' hiring standards. Journal of Monetary Economics, 62(1), 123-133. https://doi. org/10.1016/j.jmoneco.2013.10.001

$\mathrm{Vu}, \mathrm{A}$. N. (2020). On the impact of quantitative easing on credit standards and systemic risk: The Japanese experience. Economics Letters. https://doi.org/10.1016/j. econlet.2019.07.005

Weißer, T., Saßmannshausen, T., Ohrndorf, D., Burggräf, P., \& Wagner, J. (2020). A clustering approach for topic filtering within systematic literature reviews. MethodsX. https://doi.org/10.1016/j. mex.2020.100831

Xiao, Y., \& Watson, M. (2019). Guidance on Conducting a Systematic Literature Review. In Journal of Planning Education and Research. https://doi. org/10.1177/0739456X17723971 